\title{
TIMELINESS DISCLOSURE OF FINANCIAL REPORTING IN INDONESIAN MINING COMPANIES
}

\author{
Dona Fauziah, Jumaiyah* and Siti Aliyah \\ Program Studi Akuntansi, Universitas Islam Nahdlatul Ulama Jepara, Indonesia
}

\begin{abstract}
This study aims to investigate empirical evidence about factors that affect the timeliness of financial reporting of mining companies listed on the Indonesia Stock Exchange. This research method uses quantitative methods. The sample selection is using a purposive sampling method. The data obtained were then tested using logistic regression analysis at a significance level of $5 \%$. The results of the study identified that company size and profitability had a positive effect on the timeliness of financial reporting. In contrast, institutional leverage and ownership do not affect the timeliness of financial reporting of mining companies listed on the Indonesia Stock Exchange.
\end{abstract}

Keywords: Timeliness, Leverage, Company Size, Institutional ownership, and Profitability.

Submitted: 31 March 2020; Revised: 10 May 2020; Accepted: 15 May 2020

*Corresponding author : mayawahidah@unisnu.ac.id

DOI: $10.24252 /$ minds.v7i1.13505

ISSN-E: 2597-6990

ISSN-P: 2442-4951

http://journal.uin-alauddin.ac.id/index.php/minds

Publisher: Program Studi Manajemen Universitas Islam Negeri Alauddin Makassar 


\section{INTRODUCTION}

Information on financial statements is crucial for interested parties such as shareholders. The financial statements will be used for decision purposes, whether to keep the shares or sell them to other parties. In addition to that, financial statements were the tool to read the development of the company. Prospective investors also use them to decide whether the company will provide benefits in the future or vice versa. The taxation agency used them to record the potential tax income in the country. Even employees need to have basic knowledge of financial statements to fulfill their obligations and receive their rights. The financial statements must not only be approved but also, more importantly, are timely (Hanifah 2020).

The availability of information at the right time is the basis for the timeliness of information quality (Enrique \& Cinta B, 2011). Timeliness of financial reporting is an essential characteristic of financial statements. Also, to minimize the risk of misinterpretation of the information presented, financial statements must be reported promptly (Sanjaya dan Wirawati, 2016), or it may decrease the benefits of the information contained in the financial statements (Brooke, Adi, \& Chad, 2014 ). Data presented in the financial statements also will lose relevance if the company makes an undue reporting delay (Verawati, 2019).

There are differences in timeliness studies in the context of leverage, company size, and institutional ownership. Afriyeni \& Marlius (2019) found that a company's leverage does not affect the timeliness of financial statement submission. This finding is in line with Dwiyani, Badera, \& Sudana (2017). However, Prasetyo, Susilawati, \& Purwanto (2016) found that leverage affects the timeliness of the company's financial statement submission. The findings in company size are also varied. Afriyeni \& Marlius (2019) discover that company size affects the timeliness of financial statement submission, while a study from Astuti \& Erawati (2018) finds otherwise. The results of institutional ownership research from Dwiyani, Badera, \& Sudana (2017) conclude that institutional ownership does not affect the timeliness of financial statement presentation. A study from Verawati (2019) finds a positive effect on the timeliness of financial reporting and also supported by Narayana \& Yadnyana (2017).

The authors decided to take the object of mining companies enlisted on the Indonesia Stock Exchange in 2016-2018, as the study in this sector were still minimum, and the presence of interesting empirical phenomenon. According to the announcement by Financial Services Authority (OJK) and Indonesia Stock Exchange (IDX), The mining sector is the latest in delivering financial statements, representing $10 \%$ of the total Mining Sector companies listing on the IDX. While other industries can minimize delays, the mining firms cannot. That is why this study aims to shed light on what factors affect the timeliness of financial reporting in this specific sector. 


\section{THEORETICAL REVIEW}

\section{Compliance Theory}

The theory of compliance has previously been studied in several social sciences, especially in the fields of psychological and sociological, in influencing an individual's compliance behavior. In compliance theory, there is a normative perspective. This normative perspective relates to what people consider to be moral and goes against individual personal interests. An individual tends to obey laws that they deem appropriate and consistent with their internal norms (Hidayat, 2017). Obedience means being obedient, obedient, submissive, obedient to teachings, or regulations (Gafar, Malisan, \& Irwansyah, 2017).

Based on the normative perspective, it should be that this compliance theory can be applied in the field of accounting. The demand for compliance with the timeliness in the submission of annual financial statements of public companies in Indonesia has been regulated in Law Number 29 / POJK.04 / 2016 concerning the yearly reports of issuers or companies. These regulations legally imply compliance with the behavior of individuals and organizations (public companies) involved in the Indonesian capital market to submit the company's annual financial statements promptly to the OJK (Afriyeni \& Marlius, 2019).

\section{Agency Theory}

The Agency Theory emphasizes the separation between the owner of the company (principal) and the manager of the company (agent) with the aim that the management of the company can be handed over to professionals who can make the company obtaining maximum profits at the same cost-efficiently possibility. In this case, the principal works to prepare the resources needed in the company's operational activities, while the agent is tasked with organizing these resources (Hastuti \& Mieranto, 2017).

One key element of agency theory is that principals and agents have different preferences or goals because all individuals act in their interests. The principal is assumed only to be interested in the financial return that will be obtained from investment in the company. The agent is expected to have an interest in compensation from managing the company (Arief, 2017). Agency theory describes that two problems occur in the relationship between principal and agent. These problems are Agency problem and Risk sharing problem. Agency theory also implies that there is information asymmetry between managers as agents and owners as principals. Information asymmetry arises when managers know more about internal information and prospects for the company in the future compared to the data obtained by principals (Afriyeni \& Marlius, 2019).

In implementing agency theory, agents must provide detailed and relevant information on funding the company's capital costs. Financial information will have benefits if it is delivered on time to users who are closely related to agency 
theory. The value of timeliness of financial reporting is vital for the usefulness of the report (Arief, 2017).

\section{Effect of Leverage on Financial Reporting Timeliness}

Leverage is a tool to measure how far a company depends on creditors in financing company assets (Hernanda 2020). Companies with high leverage mean that they are very dependent on external loans to finance their assets; otherwise, they are more likely to fund the operational with their internal capital (Dwiyani, Badera, \& Sudana, 2017). To measure leverage in this study using debt to equity ratio (DER), that is the ratio of debt to shareholder equity owned by the company. The high debt to equity ratio can reflect the high financial risk of a company. A high-risk commercial company can indicate that the company is experiencing financial distress due to high liabilities. Financial distress is terrible news for the company's external stakeholders. Companies that experience financial difficulty require a longer time in the auditing process because auditors are more careful in conducting audits. Therefore, companies experience delays in submitting financial statements. Research from Afriyeni dan Marlius (2019) proves that leverage harms the timeliness of financial reporting. Based on this explanation, the hypothesis proposed is :

H1: Leverage negatively affects the timeliness of the company's financial reporting.

\section{Effect of Company Size on Timeliness Financial Reporting}

Company size is measured by big or small of the company by looking at the total assets or total sales owned by the company (Azhari \& Nuryatno, 2019). Larger the size of the company is expected to have a faster ability to submit financial statements because large companies certainly have more resources, primarily financial or accounting staff, supported by sophisticated technology and a robust internal control system (Mareta, 2015). With the extensive resources and other supporting components, companies tend to be more timely in presenting their financial statements (Ramadhan \& Asandimitra, 2019). Large companies are also under pressure to publish financial statements on time to avoid speculation in trading in the company's shares. Research from Sanjaya dan Wirawati (2016) proves that company size has a positive effect on the timeliness of financial reporting. From the explanation of the theory above, the hypothesis proposed in this study is :

$\mathrm{H} 2$ : Company size has a positive effect on the timeliness of corporate financial reporting.

\section{Effect of Institutional Ownership on Timeliness of Financial Reporting}

Institutional ownership is the total proportion of shares owned by an institution or business entity of an organization (Susanti et al., 2020). Institutional ownership has a vital role in monitoring management because having institutional ownership will encourage increased optimal oversight (Kadir, 2011). 
The greater institutional ownership will improve management oversee with higher power and encouragement (Abdullah \& Yuliana, 2018). With supervision from outside the company, the administration is required to be able to show excellent performance, one of which is to submit financial reports promptly, because if the performance of management is excellent, shareholders will provide support for the control. Research from Verawati (2019) proves that institutional ownership has a positive effect on the timeliness of financial reporting. Based on this explanation, the hypothesis proposed in this study is :

H3: Institutional ownership has a positive effect on the timeliness of corporate financial reporting.

The Effect of Profitability on Timeliness of Financial Reporting

Profitability is one indicator of the company's success (Verawati, 2019). If profitability is lower, it will lower the company's ability to be active in the market. So it can be said that profit is good news for the company. The company will not delay the delivery of information that contains good news. Research from Astuti \& Erawati (2018) proves that profitability has a positive effect on the timeliness of the company's financial statements delivery. From the explanation of the theory above, the hypothesis proposed in this study is :

$\mathrm{H}_{4}$ : Profitability has a positive effect on the timeliness of corporate financial reporting.

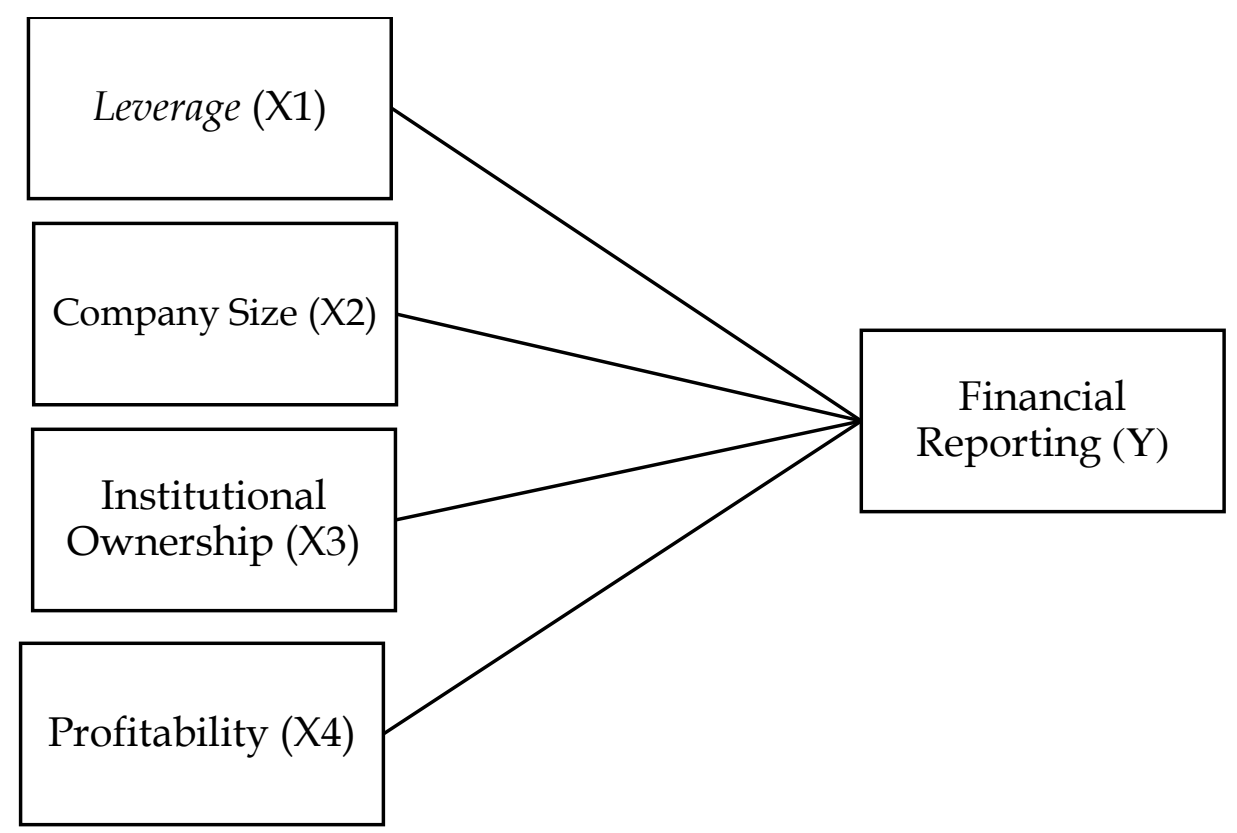

Figure 1. Theoretical Framework 


\section{METHODOLOGY}

The dependent variable in this study is the timeliness of financial statements. This dependent variable is measured based on the time range on which the audited annual financial statements are submitted to the IDX. Companies are categorized on time if the financial statements are submitted no later than April 30, while the late companies are those that provide financial reports after April 30. Timeliness is calculated using dummy variables, which were category 1 , for companies that are on time and 0 for late companies. The independent variables in this study are leverage, company size, institutional ownership, and profitability with a ratio scale.

Table 1. Operationalization of Independent Variables

\begin{tabular}{|c|c|c|c|}
\hline No & Variabel & Penjelasan & Rumus \\
\hline 1 & $\begin{array}{l}\text { Leverage } \\
(\mathrm{X} 1)\end{array}$ & $\begin{array}{l}\text { This leverage variable is } \\
\text { projected with a debt to } \\
\text { equity ratio (DER). This } \\
\text { ratio illustrates the ratio } \\
\text { of liabilities and equity } \\
\text { in corporate funding. It } \\
\text { shows the ability of the } \\
\text { company's capital to } \\
\text { meet all its obligations } \\
\text { (Van Horne dan } \\
\text { Wachowicz Jr, 2014). }\end{array}$ & $\begin{array}{l}\text { Debt to Equity Ratio (DER) = } \\
\frac{\text { amount of debt }}{\text { "Shareholder equity" }}\end{array}$ \\
\hline 2 & $\begin{array}{l}\text { Company } \\
\text { Size }(X 2)\end{array}$ & $\begin{array}{l}\text { The size of the company } \\
\text { can be assessed in several } \\
\text { ways; both the size and } \\
\text { size of the company can } \\
\text { be based on the total } \\
\text { value of assets, total sales, } \\
\text { market capitalization, } \\
\text { number of workers, etc. }\end{array}$ & $\begin{array}{l}\text { Institutional Ownership = Ln (Total } \\
\text { Asset)" }\end{array}$ \\
\hline 3 & $\begin{array}{l}\text { Institution } \\
\text { al } \\
\text { Ownershi } \\
\text { p (X3) }\end{array}$ & $\begin{array}{l}\text { Institutional ownership is } \\
\text { the proportion of share } \\
\text { ownership held } \\
\text { institutionally at the end } \\
\text { of the year measured in } \\
\text { the percentage of shares } \\
\text { owned by institutional } \\
\text { investors in a company. } \\
\text { (Widiari and Putra, 2017). }\end{array}$ & $\begin{array}{l}\text { Institutional ownership }= \\
\frac{\text { total Institutional ownership shares }}{\text { total shares outstanding }} \times 100 \%\end{array}$ \\
\hline 4 & $\begin{array}{l}\text { Profitabi } \\
\text { lity }(X 4)\end{array}$ & $\begin{array}{l}\text { The profitability of a } \\
\text { company reflects the } \\
\text { level of effectiveness } \\
\text { achieved by a company's } \\
\text { operations. }\end{array}$ & Return On Asset $(\mathrm{DER})=\frac{\text { profit after tax }}{\text { total assets }}$ \\
\hline
\end{tabular}

This research is a quantitative study by taking data from Mining Sector Companies that are listing on the Indonesia Stock Exchange Period 2016-2018. Companies registered with the sector are 50 companies. The research sample was 
selected using a purposive sampling technique, meaning that the sample used in this study was a sample that met specific criteria. The purpose of using this method is to obtain a representative sample. The criteria used in sampling are as follows:

Table 2. Sampling Criteria

\begin{tabular}{|c|c|c|c|}
\hline No & Criteria & $\begin{array}{l}\text { Does not } \\
\text { meet }\end{array}$ & Accumulation \\
\hline 1 & $\begin{array}{l}\text { Mining Sector Companies listing on the } \\
\text { Indonesia Stock Exchange in 2016-2018 }\end{array}$ & & 50 \\
\hline 2 & $\begin{array}{l}\text { Companies that submit financial reports to } \\
\text { the Indonesia Stock Exchange in 2016-2018 }\end{array}$ & $(12)$ & 38 \\
\hline 3 & $\begin{array}{l}\text { The selected company is a company that } \\
\text { has complete data about financial } \\
\text { statements relating to the measurement of } \\
\text { the variables used in this study }\end{array}$ & (7) & 31 \\
\hline 4 & $\begin{array}{l}\text { Companies that did not include losses } \\
\text { during the study period }\end{array}$ & $(10)$ & 21 \\
\hline & Number of Sample Companies & & 21 \\
\hline & Number of Years of Observation & & 3 \\
\hline & Number of Research Samples & & 63 \\
\hline
\end{tabular}

In this study, the data processing method was carried out on Mining Sector companies listed on the Indonesia Stock Exchange. This study obtained data through the official website of the Indonesia Stock Exchange, i.e., www.idx.co.id. Then the data is processed using logistic regression models with the help of software IBM SPSS (Statistical Product And Service Solution) version 23.0.

Analysis of the data used in this study was grouped into two parts. The first part is a descriptive statistical analysis conducted to determine the distribution of research data. The second part is the analysis of the research hypothesis using a logistic regression test. Logistic regression is a regression model that has been modified so that its characteristics are no longer the same as a simple or multiple regression model. Therefore the determination of significance is statistically different. Logistic regression test is used to determine whether leverage, company size, institutional ownership, and profitability affect the timeliness of financial reporting. To find out how much the independent variable influences the dependent variable, the researcher uses the following logistic regression equation :

$$
\operatorname{Ln}\left(\frac{T L}{1}-T L\right)=a-b_{1} D E R+b_{2} S I Z E+b_{3} K I+b 4 R O A+e
$$

Notes :

$$
\begin{array}{ll}
\operatorname{Ln}\left(\frac{T L}{1}-T L\right) & =\text { Timeliness of corporate financial reporting } \\
a & =\text { A constant }
\end{array}
$$




$\begin{array}{ll}\text { DER } & =\text { Leverage } \\ \text { SIZE } & =\text { Company Size } \\ \text { KI } & =\text { Institusional Ownership } \\ \text { ROA } & =\text { Profitabily } \\ e & =\text { Error }\end{array}$

\section{RESULTS}

\section{Descriptive Statistics}

Descriptive statistics of research variables are carried out to analyze the data by providing an overview of explanations that interpret the results of the analysis of the data that has been collected and researched. Data processed in SPSS consists of leverage (DER), company size (SIZE), institutional ownership (KI), and profitability (ROA), which can later be known as mean, maximum value, minimum value, and standard deviation of each variable. The variable timeliness of financial reporting (TL) is not included because the variable is a nominal scale, so there is no need to know the mean, maximum value, minimum value, and standard deviation (Anjani, 2019). Based on the results of data processing with SPSS 23.0, the following calculation results are obtained:

Table 3. Descriptive Statistics

\begin{tabular}{|c|c|c|c|c|c|}
\hline & $\mathrm{N}$ & Minimum & Maximum & Mean & St.Dev. \\
\hline$\overline{\mathrm{DER}}$ & 63 & -2.11 & 11.91 & 1.3548 & 1.88327 \\
\hline SIZE & 63 & 16.14 & 22.68 & 19.7908 & 1.54227 \\
\hline KI & 63 & 12.97 & 97.39 & 62.9555 & 24.00617 \\
\hline ROA & 63 & .00 & 1.00 & .1210 & .15298 \\
\hline $\begin{array}{l}\text { Valid N } \\
\text { (listwise) }\end{array}$ & 63 & & & & \\
\hline
\end{tabular}

Descriptive statistics of the research variables in the mining company that was sampled in this study can be explained as follows :

1. From table 2 above, the lowest (minimum) variable leverage (DER) of -2.11 is recognized at PT Bumi Resources Tbk. While the highest number (maximum) of 11.91 at PT Bumi Resources Tbk. The average value (average) of 1.3548; this ratio is still acceptable generally because the company is still able to pay its debts with a turnover of 1.3548 times. Meanwhile, the standard deviation is 1.88327 .

2. In the company size variable (SIZE), the results of the descriptive analysis show an average value (mean) of 19.7908 and a standard deviation of 1.54227. The minimum amount 16.14 is at PT Mitra Investindo Tbk, and the maximum value 22.68 is at PT Adaro Energy Tbk.

3. The results of the descriptive analysis for variable institutional ownership (KI) show an average value of 62.9555 and a standard deviation 24.00617. The minimum amount 12.97 is at PT Bumi Resources Tbk, and the maximum value is 97.39, which is at PT Cita Mineral Investindo Tbk.

4. The results of descriptive analysis of the profitability variable (ROA) show an average value (mean) of 0.1210 , indicating that from an average, the 
company has $0.1210 \%$ of the company's ability to convert profits into assets that can be rotated again to make a profit. And the standard deviation of 0.15298. The minimum (low) value of 0.00 is at PT Surya Esa Perkasa Tbk, the company PT. Surya Esa Perkasa Tbk cannot change revenue to repurchase assets, the company may use up its income for operational costs and debt repayments, and a maximum (high) value of 1.00, namely at PT PT Samindo Resources Tbk. This means that this company can profit in spending assets then rotated to look for income and income to generate profits

Tabel 4. Timeliness Description

\begin{tabular}{clrrrr}
\hline & & & \multicolumn{2}{c}{ Valid } & Cumulative \\
& & Frequency & Percent & Percent & Percent \\
\hline Valid Late & 7 & 11.1 & 11.1 & 11.1 \\
In time & 56 & 88.9 & 88.9 & 100.0 \\
Total & 63 & 100.0 & 100.0 & \\
\hline
\end{tabular}

Table 3 shows a total sample of 63 , with code (1) for the on-time while the (0) for the lates. Companies that are not on time amounted to 7 or $11.1 \%$. Inaccuracy in financial reporting on the company is influenced by several factors, while the first factor is the lack of proper management control in the company. Secondly, there is no special attention from shareholders with no warning to the company management; third is influenced by the lack of sources of low human power. While companies that were on time were 56 or $88.9 \%$ of the sample, of the 56 companies, it can be ensured that the company's resources can be relied on, the company's management is neatly organized, and there are caring company owners.

\section{Hypothesis Test}

\section{Overall Model Test}

Overall model fit test by looking at numbers -2 Log Likelihood. Likelihood L from the model is the probability that the hypothesized model illustrates the input data. To test the null and alternative hypotheses, $\mathrm{L}$ is transformed into 2LogL, and this statistic is called Likelihood ratio $x 2$ statistics. The overall test results of the model in this study are as follows :

Table 5 Iteration History

\begin{tabular}{rrrr}
\hline Iteration & $\begin{array}{c}-2 \text { Log } \\
\text { likelihood }\end{array}$ & $\begin{array}{c}\text { Coefficients } \\
\text { Constant }\end{array}$ \\
\hline Step 0 & 1 & 45.908 & 1.556 \\
2 & 43.999 & 1.995 \\
3 & 43.953 & 2.077 \\
4 & 43.953 & 2.079 \\
5 & 43.953 & 2.079 \\
\hline
\end{tabular}


Table 6 Iteration History

\begin{tabular}{llrrrrrr}
\hline \multirow{2}{*}{$\begin{array}{l}\text { Iteration } \\
\text { Step 1 }\end{array}$} & \multicolumn{2}{c}{$\begin{array}{c}\text { - Log } \\
\text { likelihood }\end{array}$} & Constant & \multicolumn{1}{c}{ DER } & \multicolumn{2}{c}{ SIZE } & \multicolumn{2}{c}{ KI } & \multicolumn{2}{c}{ ROA } \\
& 1 & 32.344 & 4.645 & -.320 & -.165 & .009 & .502 \\
& 2 & 24.284 & 8.063 & -.467 & -.335 & .020 & 2.013 \\
& 3 & 20.939 & 10.839 & -.484 & -.513 & .036 & 6.171 \\
& 4 & 18.691 & 12.547 & -.454 & -.650 & .052 & 15.116 \\
& 5 & 15.542 & 15.900 & -.446 & -.888 & .063 & 42.079 \\
& 6 & 13.211 & 23.416 & -.487 & -1.382 & .095 & 83.219 \\
& 7 & 12.761 & 28.549 & -.563 & -1.711 & .122 & 105.215 \\
& 8 & 12.724 & 30.257 & -.595 & -1.825 & .135 & 111.798 \\
& 9 & 12.723 & 30.442 & -.599 & -1.839 & .137 & 112.519 \\
& 10 & 12.723 & 30.445 & -.599 & -1.839 & .137 & 112.530 \\
& 11 & 12.723 & 30.445 & -.599 & -1.839 & .137 & 112.530 \\
\hline
\end{tabular}

The Iteration History table above shows the numbers -2 Log-Likelihood step 0 is 43,953, and the -2 Log-Likelihood step 1 number is 12,723. This shows a decrease in the $-2 \log$ Likelihood value of 31,230 . There is a decrease at $-2 \log$ Likelihood, so the null hypothesis is accepted (the model hypothesized fit with the data), and it can be concluded that overall the logistic regression model is good.

\section{Coefficient of Determination Test}

The purpose of the Coefficient of Determination (R2) is to measure how high the combination of independent variables is and to explain the dependent variable (Ghozali, 2016). Test the coefficient of determination using the Nagelkerke R Square value. The results of the determination coefficient test are as follows :

Table 7 Nagelkerke R Square

\begin{tabular}{lccc}
\hline & -2 Log & Cox \& Snell & Nagelkerke \\
Step & likelihood & R Square & R Square \\
1 & $12.723^{a}$ & .391 & .778 \\
\hline
\end{tabular}

Seen in the table above shows the value of Nagelkerke R Square is 0.778 , which means that independent variables can explain variables is $77.8 \%$. Other variables outside the research model explain the remaining $22.2 \%$ besides the leverage (DER), company size ( SIZE), institutional ownership (KI), and profitability (ROA) variable.

\section{The goodness of Fit Test}

The goodness of fit test in this study uses the Hosmer, and Lemeshow Test conducted to determine whether the data used under the model. If a statistical value Hosmer and Lemeshow Test Goodness of Fit $>0,05$, then the null hypothesis cannot be rejected, and the model can predict the number of its observations, or the model can be said to be accepted because it matches the observational data (Ghozali, 2016). The results of the goodness of fit test of the regression model are as follows: 
Table 8 Hosmer and Lemeshow Test

\begin{tabular}{cccc}
\hline Step & Chi-square & df & Sig. \\
\hline 1 & .662 & 8 & 1.000 \\
\hline
\end{tabular}

From Hosmer and Lemeshow Test table above show value Chi-Square of 0,662 with a significance value of 1,000 greater than 0.05 . Significance level $>0,05$, then the null hypothesis cannot be rejected (H0 is accepted), so this regression model is feasible to use for further analysis.

4. Regression Coefficient Test

Table 9 Variable in the Equation

\begin{tabular}{ccccccc} 
& & B & S.E. & Wald & df & Sig. \\
\hline \multirow{4}{*}{ Step 1a } & DER & -.599 & .361 & 2.752 & 1 & .097 \\
& SIZE & 1.839 & .873 & 4.439 & 1 & .035 \\
& KI & .137 & .094 & 2.102 & 1 & .147 \\
& ROA & 112.530 & 51.817 & 4.716 & 1 & .030 \\
& Constant & 30.445 & 15.620 & 3.799 & 1 & .051 \\
\hline
\end{tabular}

Based on the regression model above, it can be described as follows:

a. The testing of the first hypothesis is done by testing the significance of the regression coefficients of the leverage variable. The first hypothesis of this study states that the negative effect on the timeliness of financial reporting. The significance value in this variable is 0.097 , with the magnitude of the regression coefficient of -0.599 . At the significance level $a=5 \%$, the regression coefficient is not significant because the significance of $0.097>$ 0.05 , it can be concluded that leverage affects negatively but not significantly to the timeliness of financial statements that produce the first hypothesis (H1) is rejected

b. Testing the second hypothesis is done through testing the significance of regression coefficients for firm size variable. The second hypothesis of this study states that company size has a positive effect on the timeliness of financial reporting. The significance value in this variable is 0.035 , with the size of the company size regression coefficient of 1.839. At the significance level $a=5 \%$, the regression coefficient is significantly positive because the significance is $0.035<0.05$ with a positive regression coefficient, it can be concluded that, company size has a positive effect on the timeliness of financial reporting so that the second hypothesis $(\mathrm{H} 2)$ be accepted.

c. The testing of the third hypothesis is done by testing the significance of the regression coefficient of institutional ownership variables. The third hypothesis of this study states that institutional ownership has a positive effect on the timeliness of financial reporting. The significance value in this variable is 0.147 , with the regression coefficient for institutional ownership is 0.137 . At the significance level $\alpha=5 \%$, the regression coefficient is not significant because the significance is $0.147>0.05$, it can be concluded that 
institutional ownership does not affect the timeliness of financial reporting so that the third hypothesis $(\mathrm{H} 3)$ rejected.

d. Testing the third hypothesis is done through the profitability variable. The fourth hypothesis of this study states that profitability has a positive effect on the timeliness of financial reporting. The significance value in this variable is 0.030 , with a profitability regression coefficient of 112.530 . At the significance level $a=5 \%$, the regression coefficient is significantly positive because the significance is $0.030<0.05$ with a positive regression coefficient, then it can be concluded that, profitability has a positive effect on the timeliness of financial reporting so that the fourth hypothesis (H4) rejected

\section{DISCUSSION}

\section{Effect of Leverage on Financial Reporting Timeliness}

The results of this study indicate that leverage shows a significant positive effect on the timeliness of financial reporting. This shows a high level of economic advantage. An entrepreneur does not determine the timeliness of financial statements. The higher the leverage, the more capital is needed than the debt; the higher the force, the higher the ability of the company to accept it. The results of research on sectoral companies in the 2016-2018 period showed that negative leverage was not significant to the timeliness of financial reporting. The agency explains the participation between the owner as the principal and the manager as the agent trying to utilize the utility function (Jensen and Meckling, 1976).

Companies that have low leverage can also be companies that will provide timely financial reports from research data that can be known about companies that have a high level of economic influence such as PT Surya Esa Perkasa Tbk. The results of the study do not conflict with the results of research that prove the effect on the timeliness of the submission of the company's financial statements. This gives the conclusion that the ratio of long-term debt capital (LT.DER) is appropriate to be used as a benchmark for the timely delivery of the company. If the value of the ratio of debt to long-term equity (LT.DER) is low, then it can reflect investor confidence (Prasetyo, Susilawati, \& Purwanto, 2016). The results of statistical tests are supported by the results of research that states. Leverage does not influence the timeliness of financial statement submission. The results of this study indicate the fact or low leverage of a company is not reasonable causes this company to report its financial statements on time or late (Susilo \& Fatmayeti, 2015).

\section{Effect of Company Size on Timeliness of Financial Reporting}

The results of this study indicate that company size has a positive effect on the timeliness of financial reporting. This reflects that company size is consistently a fundamental factor affecting the phenomenon of financial reporting in the capital market (Wirakusuma \& Cindrawati, 2016). Larger the size of the company, faster the ability to submit financial statements, because a large company certainly has more resources. With extensive resources and other supporting components, companies tend to be more timely in presenting their 
financial statements (Mareta, 2015). What happens in the company is under the theory of compliance, which states that the company will take normative actions. This perspective has to do with morals and goes against individual personal interests. An individual tends to obey the laws or rules that exist in the company that they deem appropriate and consistent with their internal norms (Hidayat, 2017).

The results of this study are supported by the results of the analysis which shows that company size has a significant effect on the timeliness of financial statement presentation. The larger the company, the more resources and information systems it has. Large companies also get proper supervision from investors, regulators, and the public (Jennifer, Isabel, \& Beatriz, 2013), so that it will cause large companies to more quickly complete their financial statements (Darmawati \& Noor, 2018).

\section{Effect of Institutional Ownership on Timeliness of Financial Reporting}

The results of this study indicate that institutional ownership does not affect the timeliness of financial reporting. The insignificant effect occurs because companies that have a large or small percentage of institutional ownership both want their financial reports to be published immediately. The higher institutional purchase of a company will not increase opportunities/possibilities for companies to submit financial statements promptly. This result occurs because companies that have a high percentage (large) or low (small) want to provide their financial reports as soon as possible. Companies with external institution ownership, both small and large, have the same responsibility, for reporting the results of their performance over a period to the owner of the company. What happens to this company is per the theory of compliance where the company will report its finances by the Financial Services Authority (OJK) 29 / POJK.04 / 2016 regulations on the annual reports of issuers or public companies that the company must report financials within 90 days or April 30 of the following year.

The owner wants to know the development of the company's business as soon as possible to determine what strategic policies to do. In addition to attracting other parties who use financial statements such as potential investors and prospective creditors, the company must submit its financial statements on time. Potential investors are potential targets for the company. Therefore to be able to attract the attention of investors, the company must be able to provide excellent performance by reporting/submitting financial statements on time.

Based on research data, it can be seen that companies who have a large percentage of institutional ownership, such as PT Cita Mineral Investindo Tbk with institutional ownership of $97.39 \%$, submit financial statements on time. Companies with a small percentage of institutional ownership provide financial reports promptly as well such as PT Mitra Investindo Tbk, with institutional ownership of $29.87 \%$. The results of this statistical test are supported by research, which results in institutional ownership not affect the timeliness of financial reporting. Institutional ownership does not affect the timeliness of financial reporting allegedly due to lack of supervision from the institution as a 
shareholder. The institution is more concerned with numbers in financial statements, especially profit (profit) rather than the time of submission of financial statements (Azhari \& Nuryatno, 2019). This difference occurs because of differences in sample and year of study.

\section{The Effect of Profitability on Timeliness of Financial Reporting}

The results of this study indicate that profitability has a positive effect on the timeliness of financial reporting. In this study, profitability shows the company's success in making profits. Profit is good news for companies. Companies that make profits will tend to be more on time to report the company's finances. If the earnings announcement contains good news, then management will be more likely to report on time and vice versa. The signal theory states that in a situation where the company benefits, the company will use the information to give signals to investors to support the continuity of current management positions and higher compensation to management (Mark \& Russell, 1993). With this theory that the company will immediately provide information when the company's performance is good than when the company's performance is poor. One explanation of this action is based on signal theory.

The results of this research are in line with research, which states that the test results with logistic regression show profitability have a positive effect on the timeliness of financial statement presentation. Companies that can produce optimal profits will tend to be more timely in delivering financial reporting than companies that suffer losses. Companies that have high profitability can be said that the financial statements contain good news where companies will tend to submit their financial statements on time (Dwiyani, Badera, \& Sudana, 2017).

\section{FURTHER STUDY}

Limitations in this study were only 4 (four) variables analyzed. The next research is expected to be able to add other independent variables that are not needed in this study, such as public ownership, liquidity, old companies, complicated business, and the quality of internal auditors provided a more extensive exploration of the topic.

\section{REFERENCES}

Abdullah, M. W., \& Yuliana, A. (2018). Corporate Environmental Responsibility: An Effort To Develop A Green Accounting Model. XXII(03), 305-320.

Afriyeni, \& Marlius, D. (2019). Analisis Faktor-faktor Yang Berpengaruh Terhadap Ketepatan Waktu Penyampaian Laporan Keuangan Pada PErusahaan Yang Listing di Bursa Efek Indonesia. Osf Preprint, 1-17.

Afriyeni, \& Marlius, D. (2019). Analisis Faktor-faktor Yang Berpengaruh Terhadap Ketepatan Waktu Penyampaian Laporan Keuangan Pada

PErusahaan Yang Listing di Bursa Efek Indonesia. Osf Preprint, 1-17

Anjani, R. L. (2019). Faktor-faktor Yang Mempengaruhi Ketepatan Waktu Pelaporan Keuangan. Skripsi, Tidak Diterbitkan. Fakultas Ekonomi dan Bisnis.Universitas Islam Nahdlatul Ulama Jepara 
Arief, Z. (2017). Analisis Faktor-faktor Yang Mempengaruhi Ketepatan Waktu Pelaporan Keuangan. Tidak Diterbitkan. Fakultas Ekonomi dan Bisnis.Universitas Islam Nahdlatul Ulama Jepara

Astuti, W., \& Erawati, T. (2018). Pengaruh Profitabilitas, Umur Perusahaan dan Ukuran Perusahaan Terhadap Ketepatan Waktu Penyampaian Laporan Keuangan Perusahaan. Jurnal Kajian Bisnis, Vol. 26, No. 2, 144-157.

Azhari, F., \& Nuryatno, M. (2019). Peran Opini Audit Sebagai Pemoderasi Pengaruh Profitabilitas, Ukuran Perusahaan, Kepemilikan Institusional, dan Komite Audit Terhadap Ketepatan Waktu Pelaporan Keuangan. JRAMB, jurnal Riset Akuntansi, Mercu Buanat, 1-18.

Darmawati, D., \& Noor, I. N. (2018). Pengaruh Kepemilikan Institusional Terhadap Ketepatwaktuan Penyajian Laporan Keuangan. Prosiding Seminar Nasional Cendekiawan, 961-966 Vol 6 No 4

Dwiyani, S. A., Badera, I. N., \& Sudana, I. P. (2017). Faktor-faktor Yang Mempengaruhi Ketepatwaktuan Penyajian Laporan Keuangan. E-Jurnal Ekonomi dan Bisnis Universitas Udayana, 1451-1480.

Enrique , B., \& Cinta B, B. (2011). Analysis The Timelliness Of Financial Statements Submitted By Companies of The Spanish Continuous Market . review of Economic Business studies , 63-87. Vol 4 Edisi 2

Gafar, A., Malisan, L., \& Irwansyah. (2017). Faktor-Faktor yang Mempengaruhi Ketepatan Waktu Penyampain Laporan Keuangan pada Perbankan yang Terdaftar di Bursa Efek Indonesia. Forum Ekonomi, 42-52

Ghozali, I. (2016). Aplikasi Analisis Multivariate Dengan Program SPSS. Semarang: Badan Penerbit Universitas Diponegoro.

Hanifah S , Sarpingah S , Yananto M.P, (2020). The Effect of Level of Education, Accounting Knowledge, and Utilization Of Information Technology Toward Quality The Quality of MSME's Financial Reports. ACEBISS 2019, March 26-30, Jakarta, Indonesia

Hastuti, J., \& Mieranto, W. (2017). Pengaruh Efektivitas Komite Audit Terhadap Ketepatan Waktu Penyampaian Laporan Keuangan. Diponegoro Journal of Accounting, 1-15.

Hidayat, M. M. (2017). Analisis Faktor-faktor Yang Mempengaruhi Ketepatan Waktu Pelaporan Keuangan. Tidak Diterbitkan. Fakultas Ekonomi dan Bisnis.Universitas Islam Nahdlatul Ulama Jepara

Jennifer , M. F., Isabel , M. S., \& Beatriz, C. B. (2013v). Effect of Financial Reporting Quality on Sustainability. Corporate Sosial Responsibility and enviromental management , 45-64.Vol 22 Issu 1.

John L, L. A., Brooke , B., Adi , M., \& Chad , S. (2014 ). The association between characteristics of audit committee accounting experts, audit committee chairs, and financial reporting timeliness. Advances In Accounting , 283-297. Vol 30 Issu 1.

Kadir, A. (2011). Faktor-faktor Yang BerpengaruhTerhadap Ketepatan Waktu Pelaporan Keuangan. Jurnal Manajemen dan Akuntansi, 1-12. Vol 12 No 1 
Mareta, S. (2015). Analisis Faktor-faktor Yang Memengaruhi Timliness Publikasi Laporan Keuangan Periode 2009-2010. Jurnal Akuntansi/Volume XIX, No. 01, 93-108.

Narayana, D. A., \& Yadnyana, I. K. (2017). Pengaruh Struktur Kepemilikan, Financial Distress, dan Audit Tenure Pada Ketepatwaktuan Publikasi Laporan Keuangan. E-Jurnal Akuntansi Universitas Udayana, 2085-2114.

Pane dh, Erlina, Amalia K (2020). The Influence Of Firm Size, Profitability, Solvability, Reputation Of The Auditors And Audit Committee On The Timeliness Reporting Of Manufacturing Companies In Indonesia Stock Exchange In 2015 - 2017. JPBAF 1-9 Vol 3 No 1

Prasetyo, A. D., Susilawati, R. E., \& Purwanto, N. (2016). Pengaruh Profitabilitas, Leverage, Likuiditas, Opini Akuntan Publik, dan Rasio Aktivitas Terhadap Ketepatan Waktu Penyampaian Laporan Keuangan. Jurnal Riset Mahasiswa Akuntansi, 1-13

Ramadhan, A. Y., \& Asandimitra, N. (2019). Determinants Of Financial Management. 6(2), 129-144. https:/ / doi.org/10.24252/minds.v6i2.9506

Sanjaya, I. D., \& Wirawati, N. P. (2016). Analisis Faktor-faktor Yang Mempengaruhi Ketepatan Waktu Pelaporan Keuangan Pada Perusahaan Manufaktur Yang Terdaftar de BEI. E-Jurnal Akuntansi Universitas Udayana, $1-26$.

Susanti, Pranyoto, Edi, Badri, Elhando Rico, \& Sartika A.P (2020). Political Connection and Tax Avoidance: Evidence from Indonesia. International Journal of Psychosocial Rehabilitation, 1130-1150 Vol. 24 Issue 1

Susilo, T. P., \& Fatmayeti, S. (2017). Analisis Pengaruh Profitabilitas, Ukuran Perusahaan, Umur Perusahaan, Leverage, dan Likuiditas Terhadap Ketepatan Waktu Penyampaian Laporan Keuangan. Media Riset Akuntansi, 1-24. Vol 5 No 1

Verawati, N. (2018). Pengaruh Profitabilitas dan Struktur Kepemilikan Perusahaan Terhadap Ketepatan Waktu Pelaporan Keuangan. AKBIS Media Riset Akuntansi dan Bisnis 45-56. Vol 2 No 2

Verawati, N. (2019). Pengaruh Profitabilitas dan Struktur Kepemilikan Perusahaan Terhadap Ketepatan Waktu Pelaporan Keuangan. Jurnal Akuntansi Bisnis, 45-56.

Wirakusuma, M. G., \& Cindrawati, P. M. (2011). Pengaruh Profitabilitas, Solvabilitas, Reputasi Auditor, Ukuran Perusahaan, Kandungan Laba, dan Jenis Industri Pada Ketidaktepatwaktuan Publikasi Laporan Keuangan. Jurnal Ilmiah Akuntansi dan Bisnis, 1-27. Vol 6 No 2 